\title{
Expression of estrogen receptors alpha (ERs $\alpha$ ) and folliculogenesis profile in ovary of the rats ovarian hypofunction model
}

\author{
Aulia Firmawati*1), Mitra Artha Kurnia Hutabarat ${ }^{2)}$, Herlina Pratiwi $^{3)}$ and Alibiruni Haryo ${ }^{4)}$ \\ ${ }^{1,2,3,4)}$ Faculty of Veterinary Medicine, Brawijaya University, Malang, Kode Pos 65151
}

Submitted: 20 September 2019, Accepted: 10 March 2021

\begin{abstract}
Ovarian hypofunction is one of the reproductive disorders that occur due to a decrease in ovarian function that causes animals to not experience heat. The purpose of this study was to determine the effect of GnRH antagonist hormone interventions on ovarian hypofunction model rats by looking at the expression of alpha ERs (ERs $\alpha$ ) and the profile of folliculogenesis in the ovaries. This study used two groups of female Wistar strain rats, aged 8-10 weeks, bodyweight 150-180 grams and each group contained 10 animals. Intervention gave control group, without cetrorelix acetate intervention (placebo aqua dest sterile), treatment group with the induction of cetrorelix acetate $0.0135 \mathrm{mg} / \mathrm{kg} \mathrm{BW}$ for 17 days. Observation of $\alpha$ ERs expression in the ovary was analyzed by immunohistochemical methods, and data were analyzed using T-Test analysis $(\alpha<0.05)$. Meanwhile, the folliculogenesis profile was analyzed by hematoxylin-eosin (HE) staining, then analyzed descriptively. The results of this study indicate that the treatment group given the intervention cetrorelix acetate dose $0.0135 \mathrm{mg} / \mathrm{kg}$ BW showed significantly different results compared to the control group. In the treatment group, the ERs $\alpha$ expression decreased by $82.7 \%$ compared to the control group and in the folliculogenesis profile, there was a decrease in follicular development from pre-antral follicles to antral follicles. Cetrorelix acetate interventions can have an effect on the inhibition of folliculogenesis and estrogen binding with ERs that cause anoestrous.
\end{abstract}

Keywords: Ovarian hypofunction; Rat; ERs $\alpha$; Folliculogenesis.

*Corresponding Author: auliafirmawati@ub.ac.id 


\section{INTRODUCTION}

An ovarian hypofunction is an event where the ovaries have decreased their function so that follicular development does not occur and ovulation does not occur. Ovarian hypofunction is one of the reproductive disorders that often occur in traditional breeders in Indonesia, especially in East Java. Of the 10,000 causes of reproductive disorders that were recorded by the East Java Provincial Animal Husbandry Service in 2014 , around $54.3 \%$ were cases of ovarian hypofunction. This case of ovarian hypofunction is a case that is very easy for us to find on farms, but solving the problem of this case tends to be difficult to solve because there are several factors including lack of awareness of breeders to provide feed to female livestock by following underfeeding standards, namely $10 \%$ forage feed and $3-4 \%$ concentrate feed, other than that the slow return of lust after female postpartum, environmental conditions (sanitation and environmental temperature).

Ovarian hypofunction occuring in the postpartum period, can cause anoestrus or can even cause silent heat but not accompanied by ovulation. According to Firmawati, et al., (2020) that anoestrus due to ovarian hypofunction is often associated with failure of follicular cells to respond to hormonal stimulation, changes in the quantity and quality of hormonal secretions, decreased stimulation related to ovarian hypothalamus-pituitary function which will cause decreased GnRH secretion, so there is no ovarian activity after childbirth. In the case of ovarian hypofunction, it can be caused by the lack of nutrition in livestock so that it will affect the function of the anterior pituitary so that the production and secretion of the hormones Follicle Stimulating Hormone (FSH) and Luteinizing Hormone ( $\mathrm{LH})$ are low, which causes the ovaries to not develop or ovulate. In the condition of ovarian hypofunction, the ovary will still be normal in size but the surface is smooth when the rectal palpation is examined. Facts in the field and based on several survey results prove that in addition to being able to occur in cows with BCS between 1-2 on a scale of 4, it can also occur in cows with BCS above 3 that are kept in areas with very hot temperatures.

This study was conducted to develop a method of developing ovarian pituitary mice models that were given GnRH antagonist intervention based on $\mathrm{GnRH}$ antagonists giving negative feedback on GnRH to have an inhibitory effect on the anterior pituitary so that the anterior pituitary had an impact on decreasing levels of FSH and LH secretion in the ovaries. thus inhibiting folliculogenesis and systemic estrogen secretion, in the field conditions of ovarian hypofunction, folliculogenesis inhibition occurs which is characterized by the absence of follicular development during per rectal palpation and no signs of lust.

\section{MATERIALS AND METHODS Materials}

The tools used in this study included 1 cc terumo ${ }^{\circledR}$ syringe, $3 \mathrm{cc}$ terumo ${ }^{\circledR}$ syringe, blade, surgical scissors, anatomical tweezers, serological tweezers, surgical boards, Petri dishes, and pins, microtomes, incubators, and optical microscopes.

The materials used in this study included feed in the form of rabbit pellets (SP®), husks, and sufficient water, Phosphate Buffer Saline (PBS), formalin, alcohol, xylol, $0.9 \%$ physiological $\mathrm{NaCl}$, paraffin, Hematoxillin-Eosin dyes, and entellan, PBS, primary antibody ERs $\alpha$ brand abcam ${ }^{\circledR}(\mathrm{ab} 288)$, secondary antibody labeled peroxidase, normal horse serum $2.5 \%$ brand abcam ${ }^{\circledR}$ (ab7484), hydrogen peroxide, methanol and chromogen diaminobenzidine tetrahydrochloride (DAB) brand abcam ${ }^{\circledR}$ (ab64238).

\section{Preparation of Animal Model of Ovarian Hypofunction}

Wistar rats (Rattus norvegicus) 8-10 weeks old, bodyweight 150-180 grams. Acclimatized for 7 days to be able to adapt to the new environment. Rats were given 
feed in the form of rabbit pellets (SP®) and given drinking water ad libitum. Rats were divided into 2 treatment groups including the control group, the untreated group was only given a sterile placebo aqua dest for 17 days. The treatment group cetrorelix acetate dose of $0.0135 \mathrm{mg} / \mathrm{kg} \mathrm{BW}$ was given for 17 days $(\mathrm{P})$.

\section{Making vaginal smear preparations}

The method of making vaginal smear preparations carried out in this study was by immersing cotton buds in physiological $\mathrm{NaCl}$ then the rats to be subjected to vaginal smears were placed in a dorsal lying position, after that a vaginal smear was carried out by inserting a cotton bud soaked with physiological $\mathrm{NaCl}$ in the vagina by rotating $360^{\circ}$. Then, rubbed the cotton bud on the object-glass and allowed it to dry and then fixed with alcohol. Preparations that have been fixed with alcohol and have dried are then stained with Eosin Negrosin for 15 minutes, then rinsed with running water with small water flow, and rinsed slowly. After that, the results of the vaginal swab were observed under a microscope with a magnification of $100 x$ and $400 x$ to see the vaginal cells. In this study, vaginal swabs were performed before intervening with $\mathrm{GnRH}$ antagonists to equalize the rat estrous cycle before starting the treatment in this study.

\section{Ovarian Organ Harvesting}

The mice were euthanized by the cervical dislocation method. Dislocation is a condition where the joints completely change position without any contact with each other (Manuabada and Putu, 2017). Neck dislocation is a physical euthanasia technique by separating the joints between the skull and brain from the spinal cord at the vertebrae. This technique is carried out by placing the rat in a ventral position, the nape is held with tweezers, then the base of the tail, and the whole body is pulled until the mouse dies (Isbagio, 1992).

The dead rat was necropsied by operating vertically from the posterior abdominal area to the anterior and then opening the abdominal cavity and chest cavity. Taking the ovaries is done by looking for the ovaries, taking the ovaries together with the uterus, then cutting the ovaries from the hangers. The ovaries were prepared from surrounding fat and washed with physiological $\mathrm{NaCl}$. Then put in a tissue pot that already contains $2 \%$ PFA and then make ovarian immunohistochemical and histopathological preparations.

\section{Making Ovarian histopathology preparations}

The stages of making ovarian histology preparations consist of fixation, dehydration, purification, paraffin infiltration, embedding, sectioning, sticking to glass objects, and staining. The histopathological changes that will be observed in the histopathological picture of the ovaries are the developing stages of ovarian follicles in the ovarian cortex. Follicles that do not develop and do not ovulate until they are eliminated into atresia follicles indicate that folliculogenesis is stunted. Inhibited folliculogenesis and nonoccurring ovulation may indicate the decreased ovarian function or ovarian hypofunction. This observation is done by counting the number of preantral follicles (primary and secondary) and antral follicles (tertiary and de graff).

Observation of Ovarian Alpha Receptor Estrogen (ERs $\alpha$ ) Expression

Observation of the expression of beta estrogen receptors (ERs $\alpha$ ) was observed using the immunohistochemical (CPI) method. The steps are as follows: histopathologic preparations of the ovaries without staining were incubated for $>24$ hours to facilitate deparaffinization. The preparation was immersed in xylol 3 times for deparaffinization, that is removing paraffin from the tissue as much as possible. The preparations were then immersed in alcohol with sequences $(95 \%, 90 \%, 80 \%$, $70 \%$ ) for rehydration, namely re-entering the liquid into the tissue to facilitate staining, then stored in the refrigerator $3 \mathrm{o} \mathrm{C}$ for $>24$ hours. The preparations were washed in distilled water 3 times for 3 minutes each. The preparations were immersed in $3 \%$ 
hydrogen peroxide mixed with methanol in a humidity chamber at room temperature for 40 minutes, then washed in PBS for $3 \times 3$ minutes. The preparations were incubated with $50 \mu \mathrm{L}$ of normal horse serum $2.5 \%$ for one night in a humidity chamber at $3 \mathrm{o} \mathrm{C}$ and rinsed again with PBS for $3 \times 3$ minutes. The preparation was added with anti-ERs $\alpha$ (primary antibody) as much as $40 \mu \mathrm{L}$ brand abcam ${ }^{\circledR}(a b 288)$, for one night at 3o C, then rinsed again with PBS for $3 \times 5$ minutes. The preparation was added with a secondary antibody (anti-estrogen receptor) brand abcam ${ }^{\circledR}$ (ab7484), amounting to $40 \mu \mathrm{L}$ for 60 minutes at room temperature, then washed with PBS for $3 \times 3$ minutes. One drop of peroxidase was dropped on the preparations, left for 40 minutes, then washed with PBS for $3 \times 3$ minutes. The preparation is rinsed again with distilled water until clean.

The preparation was added with $40 \mu \mathrm{L}$ of $\mathrm{DAB}$ (3,3- diaminobenzidine tetrahydrochloride) abcam ${ }^{\circledR} \quad$ (ab64238) chromogen for 20 minutes at room temperature then washed in distilled water 3 $\mathrm{x} 5$ minutes and counterstained with hematoxylin for 1 minute at room temperature. The preparation was washed again in water with a $\mathrm{pH}$ of $8,3 \times 1$ minute, and let it dry, was mounted using a stick, then the preparation was observed with an optical microscope. ERs $\alpha$ in the ovaries were observed by counting the average number of cells expressing ERs $\alpha$. Observation of ERs $\alpha$ in the ovaries can be observed in theca cells and granulosa cells. The calculation of ERs $\alpha$ was carried out at 400x magnification with 5 fields of view per slide then analyzed with the help of Immunoratio software (Ridwan et al., 2015).

\section{RESULT AND DISCUSSION The Effect of GnRH Antagonists on the Expression of Alpha Estrogen Receptors (ERsa) in the Ovaries}

There are two types of receptors on the estrogen hormone, namely alpha receptor estrogen and beta receptor estrogen, each of these estrogen receptors has different gene sub-units and has different functions when it binds to different coding genes. And to determine the expression of estrogen receptors in the ovaries, immunohistochemical methods (CPI) can be observed, which will color the specific target cells to brown (ranging from light brown to dark with a certain area of expression). ERs $\alpha$ in ovaries is expressed in the stromal, germinal epithelium, and oocytes, while ERs $\beta$ is expressed by granulosa cells and germinal epithelium. Physiologically, the ovaries express more $\beta$ ERs than $\alpha$ ERs (Wang, et al., 2000).

Based on the results of this study, the control group and the treatment group showed the expression of ERs $\alpha$ in theca cells from ovarian follicles. The brown color indicates that the theca cell expresses the presence of estrogen which binds to the estrogen receptor on the theca cell portion of the ovary. According to Cui et al., (2013) theca cells will work together with granulosa cells in synthesizing the formation of the hormone estrogen during the development, growth, and maturation phases of ovarian follicles.

The estrogens produced will stimulate the proliferation and differentiation of target cells. The differentiation process of theca cells is influenced by several factors, one of which is the Bone Morphogenic Proteins (BMP) gene and Growth Differentiation Factor-9 (GDF-9) which is expressed by the estrogen-receptor binding to estrogen in the transcription process (Young et al., 2010). The proliferation and differentiation of theca cells and granulosa cells from ovarian follicles during the maturation process of ovarian follicles will increase the secretion of estrogen levels along with the development of dominant de graff follicles which will then have an impact in the form of positive feedback on the LH hormone until an LH surge occurs to stimulate the process. ovulation.

Based on the calculation of the mean ERs $\alpha$ expression obtained in the control group $(\mathrm{K})$ was $40.6 \pm 4.2$ and the treatment group $(\mathrm{P})$ was $3.37 \pm 0.9$. The expression of 
ERs $\alpha$ in the treatment group (P) decreased by about $82.7 \%$ compared to the control group (K). This suggests that the administration of GnRH antagonists can reduce the expression of ERs $\alpha$ which will directly result in decreased binding of the estrogen hormone with the alpha receptor estrogen in the ovary of ovarian hypofunction mice. The image of the ERs $\alpha$ expression can be seen in Figure 1 below.

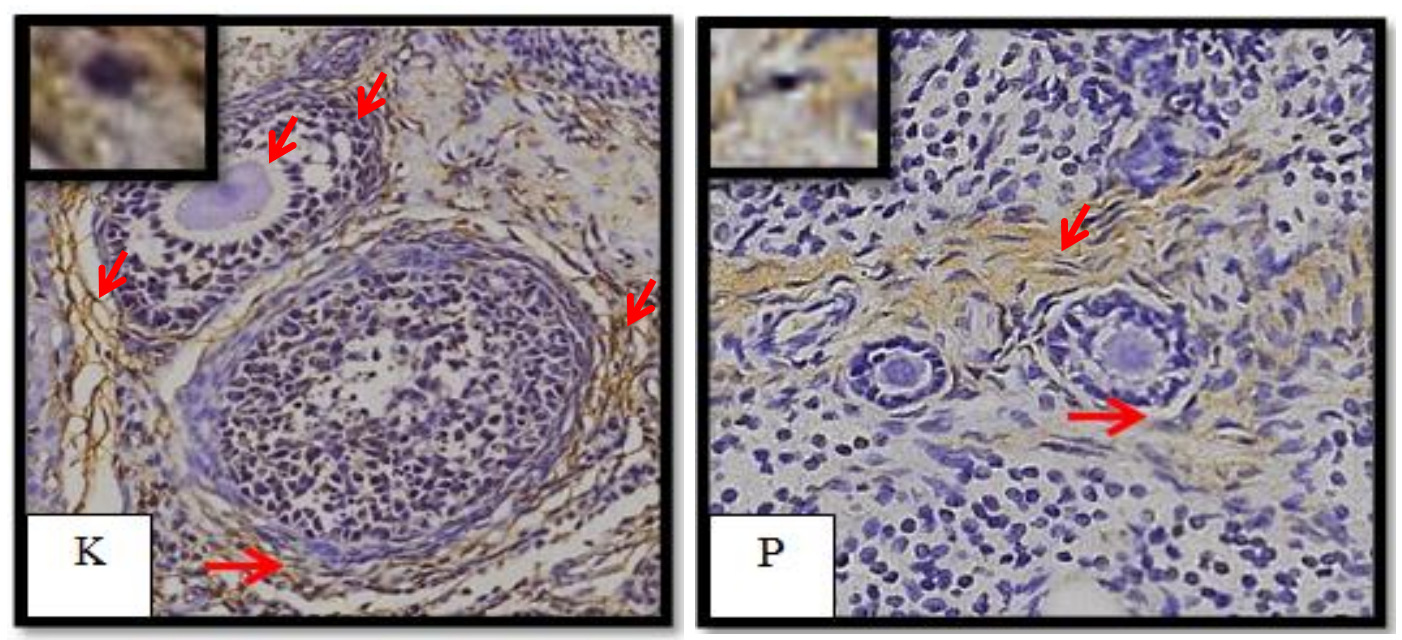

Figure 1. Expression of ERs $\alpha$ in Control Group (K) and Treatment Group (P) 400x magnification of a microscope, (): expression of ERs $\alpha$

Information: K: Control group (placebo, sterile aqua dest)

P: Treatment Group (cetrotide acetate dose of $0.0135 \mathrm{mg} / \mathrm{Kg} \mathrm{BW}$ )

Based on the results of ERs $\alpha$ expression, it can be seen that ERs $\alpha$ in the control group $(\mathrm{K})$ is expressed in the zona pellucida, internal theca and external theca cells, granulosa cells, and stromal cells, with light brown to the dark brown color intensity of ERs $\alpha$ expression. the area of expression was $85 \%$. This shows that the expression of ERs $\alpha$ is present in this area which allows the binding of the estrogen hormone with very high ERs $\alpha$ to work together to play a role in preparation for ovulation and preparation for fertilization. This is very different from the treatment group $(\mathrm{P})$, it appears that ERs $\alpha$ is only expressed in the stromal cell portion of the ovary with light brown expression intensity and $\alpha$ expression area of $30 \%$, while in the zona pellucida, internal and external theca cells are not visible. the expression ERs $\alpha$. A decrease in the expression of ERs $\alpha$ in the treatment group (P), it can cause a low bond between the estrogen hormone and the estrogen receptor, one of which is ERs $\alpha$ so that this causes low levels of estrogen in ovarian hypofunction model mice. Low levels of estrogen can cause lust and failure to ovulate.

This is by following the study of Wang et al., (2000) which states that physiologically ERs $\alpha$ in the ovary that binds to estrogen plays a role in showing sexual performance and preparation for ovulation. The decrease in expression of ERs $\alpha$ in the treatment group (P) was caused by the intervention of GnRH antagonists, in this case, cetrotide acetate in the treatment group. GnRH antagonists that are competitive with endogenous GnRH in binding to estrogen receptors will inhibit endogenous GnRH to stimulate FSH and LH in the anterior pituitary so that it will have a lowering effect on FSH stimulation and cause inhibition of follicular development while decreasing LH will inhibit the ovulation process (Anwar, 2010). Estrogen that is synthesized during the process of folliculogenesis until ovulation will experience obstacles so that it has a systemic decrease in estrogen production. The 
decrease in the production of the hormone estrogen will cause fewer hormone-estrogen receptor bonds to be formed so that the expression of the GDF-9 gene which functions in terms of follicular maturation will be disrupted so that the resulting egg cell does not occur maturation of the egg (immature ovum) if GDF-9 is disturbed then it does not. there will be a process of egg maturation and no ovulation process will occur.

\section{Effect of GnRH Antagonists on Folliculogenesis Profile}

Folliculogenesis is a process of follicular development. Follicles reach maturity through several stages of development, namely: primordial follicles, primary follicles, secondary follicles, tertiary follicles, and de Graaf follicles. This follicle development process requires $\mathrm{FSH}$ (Follicle Stimulating Hormone) and LH (Luteinizing Hormone) hormones in carrying out the folliculogenesis process until ovulation occurs. Granulosa cells have receptors for the FSH hormone while theca cells have LH receptors. Under the influence of the LH hormone, theca cells can synthesize androgen hormones in the form of androstenedione and testosterone, while the synthesis of the hormone estrogen occurs from the aromatization of androgen hormones in granulosa cells under the influence of FSH. The presence of $\mathrm{LH}$ receptors on granulosa cells marks the end of the tertiary follicular stage. Many follicles that have developed into tertiary follicles experience atresia unless there is a high enough level of gonadotropin in the blood, especially LH so that it can push the follicle to develop to the pre-ovulation stage.

Meanwhile, what happened in the ovarian hypofunction model mice was GnRH release inhibition. This inhibition of GnRH release in ovarian hypofunction mice occurred because the mice in this study were given exogenous GnRH antagonist intervention, the presence of $\mathrm{GnRH}$ inhibition made FSH and $\mathrm{LH}$ failed to release for the folliculogenesis process, so that in the treatment group $(\mathrm{P})$ we could see that the development of antral follicles (tertiary $6.8 \pm 0.04$ and de graff $2 \pm 0.02$ ) was less than the control group $(\mathrm{K})$, without GnRH antagonists (tertiary $1 \pm 0.1$ and de graff $5 \pm 0.019$ ) and this was also the case in pre-antral follicle development (primary $5 \pm$ 0.02 and secondary $3.5 \pm 0.03)$ in the treatment group $(\mathrm{P})$ experienced a decrease in development compared to the control group $(\mathrm{K})$ (primary $9 \pm 0.048$ and secondary $8.6 \pm 0.01)$.

This is by following Firmawati, et al., (2020) stated that in cattle that have ovarian hypofunction, the ovaries will feel a smooth surface but the size of the ovaries is still classified as normal. The smooth touch of the ovaries during per rectal palpation is due to the absence of follicular development during ovarian hypofunction. The table of folliculogenesis profiles in ovarian hypofunction mice can be seen in Table 1 . below.

Table 1. Folliculogenesis Profile Data in Mice with Ovarian Hypofunction Model

\begin{tabular}{ccccccc}
\hline Perlakuan & Ulangan $(\mathrm{N})$ & \multicolumn{3}{c}{ Folikel Pre Antral } & \multicolumn{2}{c}{ Folikel Antral } \\
\cline { 3 - 7 } & & Primordial & Primary & Secondary & Tertiary & De Graf \\
\hline K & 10 & 125 & 90 & 86 & 68 & 50 \\
Average & & 12.5 & 9 & 8.6 & 6.8 & 5 \\
SD & & 0.057 & 0.048 & 0.01 & 0.04 & 0.019 \\
P & 10 & 60 & 50 & 35 & 10 & 2 \\
Average & & 6 & 5 & 3.5 & 1 & 0.2 \\
SD & & 0.01 & 0.02 & 0.03 & 0.01 & 0.001 \\
\hline
\end{tabular}

According to Kesler and Gaverick, (1982) in a case study which states that in female cattle in a condition of ovarian hypofunction, this can occur because it is caused by hormonal imbalances and deficiencies so that the animal shows symptoms of anesthesia (does not appear in heat) or estrus occurs but is not accompanied 
by ovulation. This hormonal imbalance is influenced by the function of the anterior pituitary, causing low FSH and $\mathrm{LH}$ production and preventing the ovaries from developing. The action of the anterior pituitary in secreting $\mathrm{FSH}$ and $\mathrm{LH}$ hormones itself is influenced by GnRH, in this study the action of GnRH is inhibited by exogenous GnRH antagonists, which in this study we used cetrotide acetate.
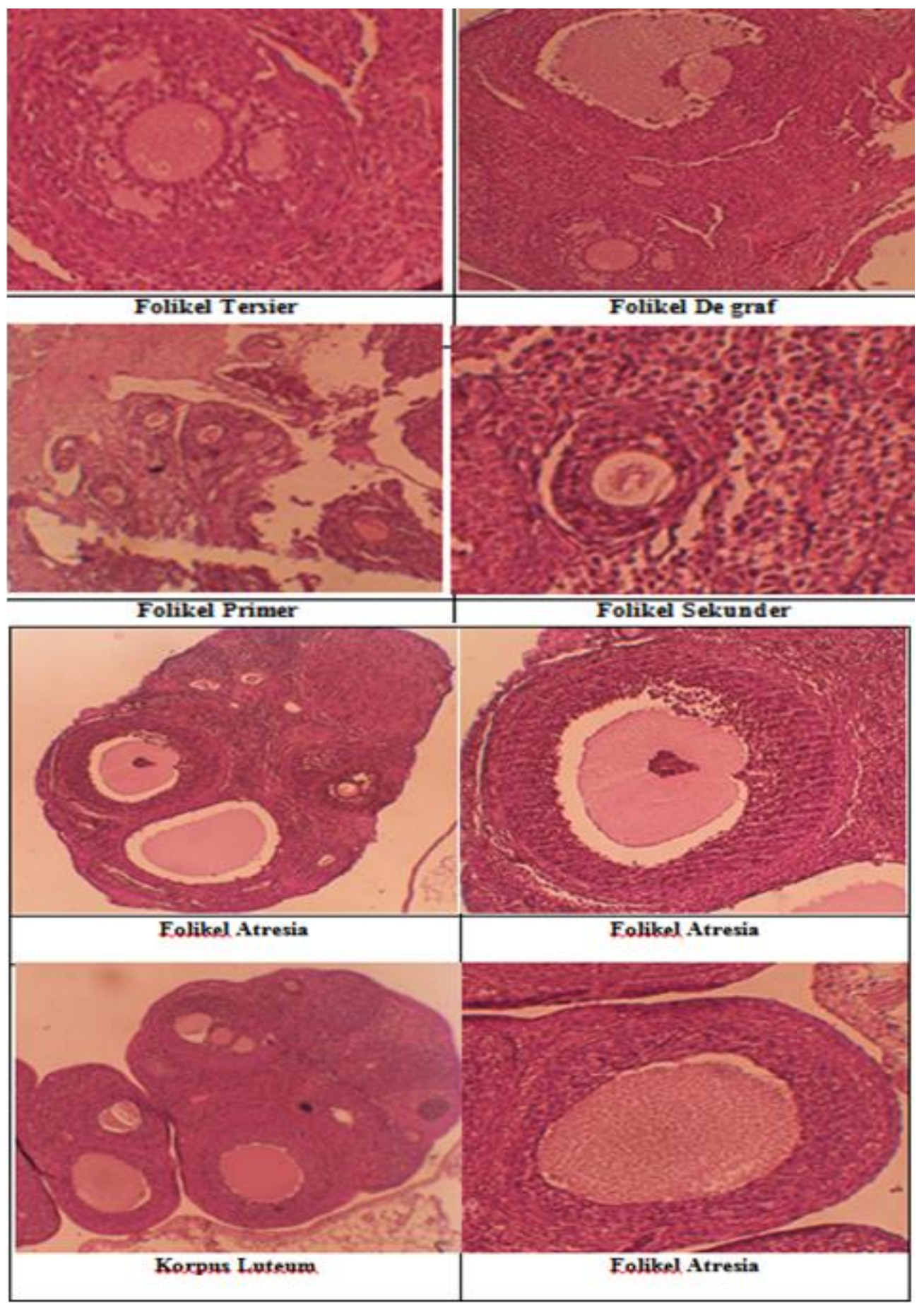

Figure 2. Histological Overview of Folliculogenesis Profile (HE, 400x magnification)

According to Griesinger et al., (2005) giving GnRH antagonists ware able to reduce $\mathrm{FSH}$ levels by $75 \%$, LH levels by $84 \%$, and estrogen until undetectable within
36 hours. The activity of the estrogen hormone requires binding with receptors to stimulate the proliferation of stromal and epithelial cells. The $\alpha$ and $\beta$ receptors work 
homologously with each other and have a high affinity for estrogen. Decreased estrogen levels due to the administration of GnRH antagonists in the treatment group (P) will reduce estrogen binding to estrogen receptors, thereby reducing the expression of estrogen receptors in both $\alpha$ and $\beta$ ERs. This causes the transcription process that occurs because the binding of estrogen and estrogen receptors decreases and causes the expression of the BMP and GDF-9 genes to also decrease, thereby interfering with the proliferation of granulosa cells in ovarian cells. Impaired cell proliferation will cause folliculogenesis inhibition in the ovaries (Cooke et al., 1998).

This folliculogenesis inhibition will result in decreased estrogen levels. The decrease in estrogen and astana estrogen levels with ERs causes no positive feedback to the hypothalamus so that GnRH does not stimulate the anterior pituitary to produce $\mathrm{LH}$, and there is no LH surge so that ovulation will never occur (Hafizuddin et al., 2012). The picture of changes in ovarian histopathology in ovarian hypofunction mice can be seen in Figure 2. below.

\section{CONCLUSIONS}

GnRH antagonist (cetrotide acetate) at a dose of $0.0135 \mathrm{mg} / \mathrm{Kg} \mathrm{BW}$ in the treatment group (P) was able to reduce ERs $\alpha$ expression and inhibit the development of ovarian follicles, namely tertiary follicles and de Graaf's follicles on ovarian histopathology in ovarian hypofunctional mice.

\section{REFERENCES}

Anwar, R. (2006). Sekresi Gonadotropin Hypofise. Universitas Padjajaran.

Cooke, P. S., Buchanan, D. L., Lubahn, D. B., \& Cunha, G. R. (1998). Mechanism of estrogen action: lessons from the estrogen receptor- $\alpha$ knockout mouse 1 . Biology of Reproduction, 59(3), 470 475. https://doi.org/10.1095/biolreprod 59.3.470

Cui, J., Shen, Y., \& Li, R. (2013). Estrogen synthesis and signaling pathways during aging: from periphery to brain. Trends in Molecular Medicine, 19(3), 197-209. https://doi.org/10.1016/j.mol med.2012.12.007

Firmawati, A., Hutabarat, M. A. K., \& Pratiwi, H. (2019). Expression of Estrogen Beta (ERs $\beta$ ) Receptor and Ovarian Histopathology Changes in Rats (Rattus norvegicus) Ovarian Hypofunction Model. Proceedings of the 6th International Conference on Advanced Molecular Bioscience and Biomedical Engineering, 41-48. https: //doi.org/10.5220/0009586400410048

Griesinger, G., Felberbaum, R., \& Diedrich, K. (2005). GnRH-antagonists in reproductive medicine. Archives of Gynecology and Obstetrics, 273(2), 71-78. https://doi.org/10.1007/s00404005-0021-2

Hafizuddin, Siregar, T. N., \& Akmal, M. (2012). Hormon dan perannya dalam folikuler pada hewan domestik. JESBIO, I(1), 21-24.

Isbagio, D. W. (2012). Euthanasia pada hewan percobaan. Media Penelitian Dan Pengembangan Kesehatan, 2(1), 18-24. https://doi.org/10.22435/mpk. v2i1.689.

Kesler, D. J., \& Garverick, H. A. (1982). Ovarian cysts in dairy cattle: a review. Journal of Animal Science, 55(5), 1147-1159. https://doi.org/10.2527/jas $1982.5551147 \mathrm{x}$

Manuaba, I. B. T. W., \& Putu, A. (2017). Buku Panduan Belajar Koas. In Ilmu Bedah. Rumah Sakit Umum Pusat Sanglah.

Ridwan, A. J., Suryanti, S., Hassan, A. H., \& Hernowo, B. S. (2015). Analysis of immunoexpression of estrogen receptor beta and extracellular matrix metalloproteinase inducer (Emmprin) on testicular seminomas nonrecurrence and recurrence. Journal Of Medicine \& Health, 1(2), 113-125. https://doi.org/ 10.28932/jmh.v1i2.507

Wang, H., Eriksson, H., \& Sahlin, L. (2000). Estrogen receptors $\alpha$ and $\beta$ in the female reproductive tract of the rat 
during the estrous cycle1. Biology of Reproduction, 63(5), 1331-1340. https: //doi.org/10.1095/biolreprod63.5.1331

Young, J. M., \& McNeilly, A. S. (2010).
Theca: the forgotten cell of the ovarian follicle. REPRODUCTION, 140(4), 489-504. https://doi.org/10.1530/REP10-0094 